\title{
PEMANFAATAN HIJAUAN PAKAN TERNAK Brachiaria Ruziziensis DAN Stylosanthes Guianenis MENDUKUNG USAHA TERNAK KAMBING DI KABUPATEN ASAHAN
}

\author{
S.Rusdiana, dan Rijanto Hutasoit \\ Pusat Penelitian dan Pengembangan Peternakan \\ J1. Pajajaran KVE.59 Bogor \\ Loka Penelitan Kambing Potong Sei Putih Medan \\ No.1 Galang Medang-Sumatera Utara
}

\begin{abstract}
System maintenance goats in Indonesia, especially in the District High King of the North Sumatra regency shavings Proopinsi done the traditional way, the availability of quality feed is one of the limiting factors to determine the number of livestock kept by farmers. The purpose of this paper is to investigate the possibilities among supplementary feeding is applied by farmers feed ingredients are easily available at affordable prices, livestock forage planted palm perkebunana dilahan the age of 5 years with extensive 3 ha forage crops forage Brachiaria and Stylosanthes ruziziensis Guianeniserta, as well as waste agriculture, which can increase the rate of goats nuts. Livestock production performance shows $R_{1}, R_{2}$ and $R_{3}$ highly significant $(P<0.01)$ higher than $R_{3}$, whereas to measure the growth rate of goats nuts $\left(R_{1}\right)$ which is the regression coefficient $Y k=14: 33+2.02 X\left(R_{2}\right)$ which is the regression coefficient $Y k=14.34+1.75 x$, and $\left(R_{3}\right)$ which regress coefficient $Y p=14.34+1.58 y$ obtained regression equation with the same value of $R^{2}=0.99$, not only petambahan weight are visible on the nut goats in ruziziensis give forage Brachiaria and Stylosanthes guianenis but goats seem nuts over fluffy, slippery, sparkling eyes, smooth and healthy. Gains derived by farmers around $R_{I}$ Rp.1.058.602/bulan B/C 1.2, $R_{2}$ around Rp.984.145/bulan B/C 1.2 due to variable expenses and the cost of production, while approximately $R 3 \quad R$ p.666.268/bulan $B / C \quad 1.1$ expenditure concentrated on variable costs, labor costs and the purchase of seeds.
\end{abstract}

Keywords : utilization, feed the goats . business analysis, whetstone

Abstrak: Sistem pemeliharaan ternak kambing di Indonesia khususnya di Kecamatan Tinggi Raja Kabupaten Asahan Proopinsi Sumatera Utara dilakukan dengan cara tradisional, ketersediaan pakan yang berkualitas merupakan salah satu faktor pembatas untuk menentukan jumlah ternak dipelihara oleh petani. Tujuan penulisan ini adalah untuk mengetahui diantara kemungkinan pemberian pakan tambahan yang diterapkan oleh petani adalah bahan pakan yang mudah didapat dengan harga yang terjangkau, hijauan ternak ditanam dilahan perkebunan kelapa sawit umur 5 tahun dengan luas tanaman hijauan 3ha hijauan Brachiaria ruziziensis dan Stylosanthes Guianeniserta, serta limbah pertanian, yang dapat meningkatkan laju pertambahan ternak kambing kacang. Penampilan produksi ternak menunjukkan $R_{1}, R_{2}$ dan $R_{3}$ sangat nyata $(P<0,01)$ lebih tinggi dibanding $\mathrm{R}_{3}$, sedangkan untuk mengukur tingkat pertumbuhan ternak kambing kacang $\left(R_{1}\right)$ koefisien regresi yaitu $Y_{k}=14.33+2.02_{X}\left(R_{2}\right)$ koefisien regresi yaitu $Y_{k}=14,34+1.75 x$, dan $\left(R_{3}\right)$ koefisien regres yaitu $Y_{p}=14,34+1,58 y$ diperoleh persamaan regresi dengan nilai $\mathrm{R}^{2}=0,99$ sama, tidak hanya petambahan berat badan saja yang terlihat pada ternak kambing kacang yang di beri hijauan Brachiaria ruziziensis dan Stylosanthes guianenis tetapi ternak kambing kacang lebih kelihatan berbulu halus, licin, mata berbinar, mulus dan sehat. Keuntungan yang diperoleh petani $\mathrm{R}_{1}$ sekitar Rp.1.058.602/bulan B/C 1,2, $\mathrm{R}_{2}$ sekitar Rp.984.145/bulan B/C 1.2 
disebabkan pengeluaran biaya variabel dan biaya produksi, sedangkan $\mathrm{R}_{3}$ sekitar Rp.666.268/bulan B/C 1,1 pengeluaran terkonsentrasi pada biaya variabel, biaya tenaga kerja dan pembelian bibit.

Kata kunci: pemanfaatan, pakan kambing. analisis usaha, asahan

\section{PENDAHULUAN}

Pentingnya upaya pengembangan dan peningkatan produktivitas ternak kambing dalam rangka menunjang usaha yang bersipat komersial, karena peluang bagi pengembangan secara nasional pada dasarnya cukup tinggi, terdapat berbagai indikator baik teknis, biologis, sosial maupun ekonomi yang kondusif bagi usaha produksi. Teknologi budidaya kambing pada prinsipnya mudah diadopsi, dan secara biologis kambing memiliki beberapa keunggulan komparatif dibandingkan dengan ruminansia lain seperti kemampuan untuk beradaptasi terhadap kondisi nutrisi dan klimat yang kurang menguntungkan. Tatang, (2003), berpendapat bahwa secara sosial penduduk Indonesia terbiasa mengkonsumsi daging kambing dan pada dasarnya kebutuhan domestik belum terpenuhi sehingga peningkatan produksi kambing potong akan terserap oleh pasar

Pengembangan ternak kambing sangat tergantung kepada sumber tanaman pakan sebagai dasar pakan utama untuk ternak ruminansia, Peningkatan jumlah ternak harus diikuti dengan upaya memenuhi kebutuhan pakan sepanjang tahun terutama tanaman pakan yang potensial dengan nilai nutrisi tinggi dan beradaptasi baik pada berbagai lingkungan Barnes dan Baylor. (1995). Kebiasaan petani di wilayah pedesaan dalam pemeliharaan ternak kambing masih sederhana dan sebagai usaha sampingan belum menyentuh ke usaha yang bersipat komersial dan sistem pemberian pakan masih mengandalkan rumput alam dengan cara digembalakan dan dilepas sekitar areal perkebunan kelapa sawit, karet, kakao, lahan pertanain yang belum ditanam, persawahan, pinggiran jalan, sebahagian petani membawanya keladang sambil bekerja dengan mengikat disekitar ladang dan semak-semak belukar khususnya di Kecamatan Tinggi Raja Kabupaten Asahan, ketersediaan hijauan pakan ternak yang berkualitas merupakan salah satu faktor pembatas meningkatnya produktivitas ternak,.
Populasi ternak kambing di Indonesia tercatat mencapai 15.655.739 ekor Statistik Pertanian (2011) yang tersebar di beberapa wilayah seperti Propinsi Sumatera Utara 619.940 ekor $(21,92 \%)$, sedangkan di Kecamatan Tinggi Raja sekitar 1.684 ekor (8,19\%) Satistik Kabupaten Asahan (2011). Sistem pemeliharaan ternak kambing di Indonesia sekitar (80\%) masih diusahakan oleh petani kecil (peternakan rakyat) yang berkembang di wilayah pedesaan. Usaha ternak kambing merupakan komponen penting dalam usahatani penduduk pedesaan karena pemeliharaan ternak kambing dalam skala kecil dapat membantu perekonomian rakyat di pedesaan dengan pemanfaatan sumberdaya alam yang tersedia di sekitarnya.

Sebagai langkah untuk mengatasi kondisi tersebut, maka perlu adanya introduksi hijauan pakan ternak yang berkualitas dan suplementasi melalui ransum atau konsentrat. Namun penggunaan konsentrat menyebabkan bertambahnya biaya yang harus dikeluarkan petani peternak. Untuk menekan biaya ransum, pemberian konsentrat dapat digantikan dengan bahan pakan limbah agroindustri potensial setempat yaitu limbah hasil pertanian dari sekitar lingkungan penduduk. Tanaman pakan yang dapat di introduksi antara lain : leguminosa Stylosanthes guianensis. merupakan jenis tanaman leguminosa, kandungan protein $18 \%$ dengan produksi bahan kering (BK) 40 ton/ha/tahun Hutasoit, (2010).

Hijauan pakan ternak yang sangat baik untuk pertumbuhan ternak kambing adalah hijauan Brachiaria ruziziensis yang memiliki kegunggulan palatabilitas dan produksi yang tinggi 120 ton $\mathrm{BK} / \mathrm{ha} /$ tahun Hutasoit et all, (2009), telah beradaptasi baik dan tersebar diberbagai agroklimat di Indonesia. Limbah dari hasil tanaman pangan dan hijauan yang berada di bawah naungan pohon perkebunan kelapa sawit yang potensial didaerah setempat merupakan salah satu sumber daya yang cukup potensial sebagai pakan ternak dan tersedia dalam jumlah besar dan relatif tersedia sepanjang waktu. Secara biologis ternak 
kambing cukup produktif dan adaptif dengan kondisi lingkungan setempat, sehingga memudahkan pengembangannya.

Pengembangan ini dapat lebih diarahkan keluar Jawa mengingat besarnya sumberdaya alam di daerah-daerah tersebut cukup potensial. Ketut, (2004). Hal ini disebabkan pakan yang diberikan biasanya berupa hijauan, terutama rumput lapangan yang rendah kandungan zat nutrisinya, karena berorientasi pada pakan lokal yang tersedia di lokasi Utomo, et al., (2005). Usaha untuk meningkatkan pertambahan bobot badan ternak kambing yang lebih baik dapat ditempuh melalui perbaikan kualitas dan kuantitas pakan, terutama penambahan pakan sebagai bahan pakan pelengkap disamping (hijauan), yang merupakan bahan pakan utama ternak ruminansia.

Diantara kemungkinan pemberian pakan tambahan tersebut yang berpeluang diterapkan pada petani mudah didapat dengan harga yang terjangkau hijauan pakan ternak yang ditanam secara sengaja di bawah naungan pohon kelapa sawit berumur 5 tahun seluas 3 . Berkaitan dengan potensi ternak kambing kacang sebagai salah satu peluang usaha yang cukup besar untuk dikembangkan dan mempunyai pangsa pasar yang khusus, semakin banyak konsumen yang memilih daging kambing, pola konsumsi (back to natura). Berdasarkan latar belakang maka tujuan penelitian ini adalah untuk mengetahui seberapa besar pendapatan petani ternak kambing dalam pegembangan dan pemanfaatan hijauan pakan ternak brachiaria ruziziensis dan stylosanthes guianenis mendukung usaha ternak kambing di Kabupaten Asahan dalam analisis ekonomi pendapatan petani ternak kambing kacang.

\section{METODE PENELITIAN}

Penelitian ini dilakukan di Kecamatan Tinggi Raja Kabupaten Asahan Propinsi Sumatera Utara dengan dana Proyek PIPP pada tahun 2012, penelitian terhadap ternak kambing kacang sebanyak 90 ekor betina dan jantan dengan rata-rata umur antara 5-7 bulan di kelompokan dalam 3 (tiga) kelompok selama \pm 4 bulan : perlakuan $\mathrm{R}_{1}, \mathrm{R}_{2}$ dan kontrol $\mathrm{R}_{3}$ masing maing kelompok, kegiatan ini merupakan inovasi teknologi yang mampu merubah sistem usaha pemeliharaan ternak kambing pada petani ternak di Kabupaten Asahan.

\section{Metode Pengamatan}

1. Perlakuan $\mathrm{R}_{1}$, pemeliharaannya ternak kambing kacang di kandangkan terus menerus selama \pm 4 bulan dengan pemberian pakan hijauan Brachiaria ruziziensis dan Stylosanthes guianenis dan limbah pertanian secara (ed linitum)

2. Perlakuan $\mathrm{R}_{2}$ pemeliharaan ternak kambing kacang di gembalakan dan di kandangkan (keduanya) tradisional selama \pm 4 bulan dengan pemeberian tambahan pakan hijauan Brachiaria ruziziensis dan Stylosanthes guianenis dan limbha pertanian secara (ed linitum)

3. Kontrol $\mathrm{R}_{3}$ pemeliharaan ternak kambing kacang di gembalakan terus menerus tradisional selama +4 bulan yang hanya mengandalkan rumput alam diareal perkebunan kelapa sawit, karet, lahan pertanian yang belum ditanami, pinggiran jalan, membawanya keladang sambil bekerja dengan mengikat disekitar ladang dan semak-semak belukar dan hasil limbah pertanian (ed linitum), sesekali petani mengarit untuk tambahan pakan ternak dengan pemberiannya pada sore hari.

4. Untuk melihat seberapa besar pendapatan petani dari masing-masing sistem perlakukan $\mathrm{R}_{1}, \mathrm{R}_{2}$ dan kontrol $\mathrm{R}_{3}$ yang berbeda dalam pemeliharaan ternak kambing kacang dengan menggunakan uji statistik (T-student) dan analisis ekonomi pendapatan petani $\mathrm{B} / \mathrm{C}$ ratio dapat dilihat dengan menggunakan metoda kuantitatif dan kualitatif serta tabel.

Hasil penanaman hijauan pakan Brachiaria ruziziensis dan Stylosanthes guianenis digunakan sebagai pakan ternak kambing pada perlakuan $\mathrm{R}_{1}, \mathrm{R}_{2}$ dan $\mathrm{R}_{3}$ sebagai kontrol, setiap ternak diberikan obat anti cacing parasit pada awal kegiatan dan diulang setiap dua bulan hijauan pakan dipanen setiap hari sesuai dengan kebutuhan ternak.

\section{Kelayakan Teknis}

Dengan dilakukan pengembangan tanaman hijauan pakan ternak Brachiaria ruziziensis dan Stylosanthes guianenis akan menjamin 
tersedianya tanaman pakan ternak yang berkualitas dan tersedia sepanjang tahun dalam mendukung berkembang ternak kambing kacang yang pada akhirnya dapat meningkatkan pendapatan petani. Kegiatan ini dilaksanakan di Kecamatan Tinggi Raja Kabupaten Asahan Sumatera Utara. Lahan yang digunakan adalah lahan petani seluas 3 ha $\left(30.000 \mathrm{~m}^{2}\right)$, masing-masing setiap jenis hijauan seluas 1 ha $\left(1000 \mathrm{~m}^{2}\right)$. Waktu penelitian dirancang selama \pm 8 bulan untuk penaman tanaman hijjauan pakan ternak, sedangkan untuk analisis ekonomi pendapatan petani ternak kambing kacang sengaja dirancang selama \pm 4 bulan. Data yang terkumpul kemudian dianalisis dengan menggunakan tabulasi secara deskritif serta analisis ekonomi

\section{Prospek dan manfaat ekonomi}

Dengan dibudidayakannya hijauan pakan ternak yang berkualitas dan tersedia sepanjang tahun akan menjamin perkembangan ternak kambing yang berdampak terhadap perkembangan ekonomi petani ternak kambing di Kecamatan Tinggi Raja Kabupaten Asahan Sumatera Utara. Biaya opersional yang dikeluarkan akan lebih sedikit karena dari segi waktu dan jarak yang ditempuh untuk memperoleh pakan akan lebih singkat, sedangkan dari segi jumlah ternak yang dapat dipelihara akan lebih banyak. Kondisi ternak akan lebih sehat karena faktor pakan yang cukup dan berkualitas. Kontribusi terhadap sektor lain sangat bermanfaat terlebih sektor pertanian dan perkebunan kelapa sawit, berkembangnya sektor peternakan akan menjamin ketersediaan pupuk kandang sebagai kompos bermanfaat terhadap pertumbuhan tanaman hijauan pakan ternak selain sawit

\section{Metode Pengolahan dan Analisis Data}

Untuk mengetahui tingkat pertumbuhan bobot badan ternak kambing kacang yang sengaja dipelihara untuk pertamabahn bobot badan dalam analsisi ekonomi pendapatan petani secara individu dilakukan penimbangan setiap satu bulan sekali selama \pm 4 bulan yang dinyatakan sebagai ulangan sehingga diperoleh data dari masing-masing perlakuan (treatment) perlakuan $\mathrm{R}_{1}, \mathrm{R}_{2}$ dan $\mathrm{R}_{3}$, sebagai kontro, sebelum dilakukan percobaan ternak kambing di biasakan dengan kondisi pakan selama adaptasi, kemudian kambing ditimbang pada bulan ke 1 (pertama) sampai dengan bulan ke 4 (empat). Mortalitas ternak yang mati selama penelitian \pm 4 bulan akan dihitung $1 \%$, pengujian statistik dalam kegiatan penelitian adalah:

a. Paired Comparison Mean T-test yaitu untuk menguji perbandingan nilai rata-rata berdasarkan skala usaha $\left(\mathrm{R}_{1}, \mathrm{R}_{2}\right.$ dan $\mathrm{R}_{3}$, ditingkat peternak digunakan uji statistik (T-student) pada bulan pertama, bulan ke dua, bulan ke tiga dan bulan ke empat selama percobaan berlangsung Sudjana, (1992). Adapun rumus dari t-hitung:

$$
t_{\text {hit }}=\frac{\bar{X}_{1}-\overline{X_{2}}}{S_{X 1-X 2}}
$$

Dimana :

$$
\begin{gathered}
\overline{\mathrm{X}}=\text { Rata-rata pada tingkat skala } \\
\text { usaha ternak kambing } \\
\mathrm{S}_{\mathrm{X} 1-\mathrm{X} 2}=\text { Galat baku }
\end{gathered}
$$

$$
\begin{aligned}
& \mathrm{S}_{\mathrm{Xi}} \\
& =\frac{\left(\Sigma_{\mathrm{Xi}}\right)^{2}}{\sum \mathrm{x}_{\mathrm{i}}{ }^{2}-\mathrm{n}}
\end{aligned}
$$

dimana :

$$
\begin{array}{ll}
\mathrm{S} & =\text { Nilai Varians } \\
\Sigma_{\mathrm{Xi}} & =\text { Skala Usaha ke- } \mathrm{i} \\
\mathrm{n}_{\mathrm{i}} & =\text { Jumlah pengamatan ke }-\mathrm{i}
\end{array}
$$

Uji regresi linear digunakan untuk mengetahui tingkat pertumbuhan ternak kambing selama percobaan berlangsung, Analisis regresi linear diaplikasikan pada pertumbuhan ternak kambing kacang atau bobot badan ternak pada tingkat: perlakukan $\left(\mathrm{R}_{1}\right),\left(\mathrm{R}_{2}\right)$ dan $\left(\mathrm{R}_{0}\right)$ sebagai kontrol, Model yang digunakan dengan persamaan adalah: Steel and Torrie (1980) Sudjana (1992)

Dimana :

$$
\mathrm{Y}_{\mathrm{i}}=\mathrm{a}+\mathrm{bX}_{\mathrm{i}}
$$

$\mathrm{Y}=$ peubah tidak bebas yaitu bobot badan ternak kambing $(\mathrm{kg})$ $\mathrm{X}=$ peubah bebas yaitu waktu penimbangan ternak kambing (bulan)

$$
\begin{aligned}
& \mathrm{a}=\text { slope } / \text { kemiringan } \\
& \mathrm{b}=\text { koefisien regresi }
\end{aligned}
$$




\section{HASIL DAN PEMBAHASAN}

\section{Kondisi umum wilayah}

Penduduk Kabupaten Asahan sebahagian besar bersuku Melayu 75\% sering juga disebut Melayu Asahan atau Melayu Batubara Kabupaten Asahan Sumatera Utara Provinsi Sumatera Utara Ibu kota Kisaran luas 11.431, $(114,31 \mathrm{~km} 2)$. Keadan alam Terdiri dari dataran rendah dan sedikit berbukit, Keadaan tanah liat merah, tanah liat putih bercampur pasir halus, wlayah administratif 7 desa. Jumlahi penduduk sekitar 1.038 .554 jiwa. Kepadatan penduduk 224,58 jiwa/km2. Koordinat: $\quad 2^{\circ} 59^{\prime} \mathrm{LU} \quad 9^{\circ} 32^{\prime} \mathrm{BT}$ Asahan merupakan salah satu Kabupaten yang berada di kawasan Pantai Timur Sumatera Utara, Secara geografis Kabupaten Asahan berada pada 2003'00"- 3026'00" Lintang Utara, 99001-100000 Bujur Timur dengan ketinggian $0-1.000 \mathrm{~m}$ di atas permukaan laut.

Kabupaten Asahan menempati area seluas 371.945ha yang terdiri dari 13 Kecamatan, 176 Desa/Kelurahan Definitif, setiap $\mathrm{Km} 2$ di Kabupaten Asahan rata-rata dihuni oleh $+292,16$ ribu jiwa dengan sebaran yang tidak merata pada setiap Kecamatan dan terakumulasi di daerah pedesaan. Konsentrasi pembangunan perekonomian Kabupaten Asahan pada tahun 2011 masih tetap mengarah kepada pembangunan pertanian, infrastruktur, pendidikan, kesehatan dan bidang perekonomian lainnya, jika dibandingkan dengan kondisi tahun 20010, pertumbuhan ekonomi Kabupaten Asahan pada tahun 2011 mengalami perlambatan.

Beberapa indikator pencapaian kinerja Pemerintah Kabupaten Asahan yang dapat digunakan sebagai tolok ukur dalam menghitung agregat pertumbuhan Satistik Kabupaten Asahan (2011), lambatnya pertumbuhan diiakibatkan oleh adanya penurunan potensi produk komoditi unggulan pada beberapa sektor, hal ini terjadi akibat adanya beberapa pergeseran alih fungsi lahan pertanian serta iklim cuaca yang kurang mendukung sehingga hasil yang dicapai tidak maksimal meskipun pemerintah telah melakukan regulasi terhadap kenaikan gaji pada sektor jasa-jasa dan buruh.

\section{Tataguna lahan di Kabupaten Asahan}

Tataguna lahan menunjukkan bahwa perkebunan merupakan bagian terbesar di daerah Tinggi Raja dan menyusul kemudian kebun campuran dan lahan sawah. Keadaan ini menggambarkan bahwa daerah Tinggi Raja adalah lahan perkebunan yang berupa usahatani ternak, sawah, sayur mayur, palawija. Dengan demikian sebagian besar dari penduduk mempunyai mata pencaharian sebagai petani. Disamping usahatani tanaman, usahatani ternak merupakan usaha yang banyak digeluti penduduk. Jumlah dan jenis ternak yang banyak diusahakan adalah ternak sapi, kerbau, kambing, domba, ayam buras, ayam ras, itik, Disnak Statistik Peternakan (2011). Tterlihat pada Tabel.1. Pada Tabel. 1 terlihat bahwa penguasaan ternak tertinggi pada ternak sapi potong sedangkan kambing peringkat ke 3 (tiga) dari ternak ayam buras dari data tersebut bahwa Kecamatan Tinggi Raja Kabupaten Asahan Propinsi Sumatera Utara sangat berpotensi untuk dapat menampung dan menunjang perkembangan sub sektor peternakan khususnya ternak ruminansia besar, kecil dan sebagaian kecil unggas.

Tabel 1. Populasi Ternak di Kecamatan Asahan Tahun 2011

\begin{tabular}{lcccccc}
\hline Desa & Sapi potong & kerbau & domba & kambing & $\begin{array}{c}\text { Ayam } \\
\text { buras }\end{array}$ & Itik \\
\hline Tinggi raja & 1371 & 4 & 255 & 294 & 450 & 121 \\
Sumber harapan & 340 & - & 270 & 394 & 3000 & 235 \\
Terusan tengah & 255 & - & 40 & 109 & 225 & 127 \\
Padang sari & 380 & - & 205 & 225 & 345 & 124 \\
Pisaa ulu & 240 & - & 350 & 181 & 325 & 118 \\
Teladan & 406 & - & 106 & 110 & 155 & 155 \\
Sidomulyo & 431 & - & 152 & 372 & 121 & 117 \\
Total & 2423 & 4 & 1278 & 1684 & 5307 & 997 \\
\hline
\end{tabular}

Sumber : Statiustik Kabupaten Asahan (2011) 


\section{Pemanfaat hijuan pakan ternak di lokasi penelitian}

Lokasi penelitian merupakan daerah pertanian, lahan kosong perkebunan karet dan kelapa. Masing-masing lokasi penelitian mempunyai agroekosistem yang sama. Persamaan dari dua lokasi tersebut adalah mempunyai sumber pakan ternak yang cukup untuk kebutuhan ternak. Areal perkebunan karet dan kelapa dapat diharapkan untuk memanfaatkan sebagai penghasil rumput untuk makanan ternak. Salah satu jalan diantaranya adalah memasukan ternak tersebut ke areal perkebunan, daya dukung untuk usaha pemeliharaan ternak kambing di peternak selain dipengaruhi oleh agroekosistem dimana daya lahan serta komoditas tanaman hijauan pakan ternak Brachiaria ruziziensis dan Stylosanthes guianenis yang diusahakan dapat dimanfaatkan oleh ternak sebagai sumber pakan yang uatama untuk pertumbuhan ternak kambing yang dipelihara dengan menggunakan $\mathrm{R}_{1}, \mathrm{R}_{2}$ dan $\mathrm{R}_{3}$ sebagai kontrol.

Dengan melihat nilai kontribusi dari hasil pendapatan petani di Kecamatan Tinggi Raja Kabupaten Asahan merupakan daerah perkebunan, lahan kosong perkebunan karet dan kelapa, kelapa sawit dan tegalan yang merupakan sumber pakan ternak kambing, seperti rumput gajah, rumput bracilia, gliricia, lamtoro, kaliandra, rumput sawah, rumput raja, rumput lapangan, rumput raket, rumput jampang, dan sisa limbah pertanian seperti dari tanaman jagung, kedelai, kacang tanah, ubi jalar, dan ubi kayu yang punya agroekosistem yang baik dan mempunyai sumber pakan ternak yang cukup banyak untuk kebutuhan dan perkembangan ternak ruminansia besar dan kecil seperti sapi, kambing dan domba.

\section{Model usaha ternak kambing kacang}

Usaha pemeliharaan ternak kambing betina dan jantan pada kegiatan ini merupakan ternak yang diperoleh dari pasar, hasil penelitian Lolit kambing Potong Sai Putih Medan dan dari peternak sekitar desa atau dari desa lain sebagai ternak kambing pembudidayaan atau penghasil daging untuk usaha pemeliharaan ternak kambing. Ternak kambing dikandangkan secara individu dengan luas $1 \mathrm{~m}^{2} / 30$ ekor. Pada kambing yang dilakukan penelitian terlebih dahulu kambing diadaptasikan dengan pemberian pakan Brachiaria ruziziensis dan Stylosanthes guianenis dan limbah pertanian dari sekitar lingkungan perkebunan kelapa sawit untuk membiasakan mengkonsumsi pakan sebelum di lalakukan penimbangan awal untuk siap dilakukan pengamatan.

Hal tersebut dilakukan karena tanaman hijauan pakan ternak Brachiaria ruziziensis dan Stylosanthes guianenis memiliki potensi sebagai sumber hijauan pakan untuk ternak ruminansia besar dan kecil yang memiliki kualitas dan produktivitas yang tinggi, tanaman ini dapat dimanfaatkan sebagai sumber protein dan energi, karena kandungan nitrogen maupun taraf kecernaan bahan kering dan organik yang tergolong tinggi. Hutasoit, (2010).

\section{Pengamatan ternak kambing}

Hasil pengamatan rataan pertambahan bobot badan kambing kacang perlakuan $\mathrm{R}_{\mathrm{I}}, \mathrm{R}_{2}$ dan kontrol $R_{3}$, dengan kondisi bobot badan awal yang hampir sama masing-masing kambing kacang perlakuan $\mathrm{R}_{1},(14,33 \mathrm{~kg}) \mathrm{R}_{2}(14,34 \mathrm{~kg})$ dan kambing kontrol $\mathrm{R}_{3}$, $(14,34 \mathrm{~kg})$ di capai bobot badan akhir sebesar $\mathrm{R}_{1}(22,44 \mathrm{~kg}), \mathrm{R}_{2}$, $(21,35 \mathrm{~kg})$ dan $\mathrm{R}_{3}(21,35 \mathrm{~kg})$ selama 4 bulan, pertambahan bobot badan harian $(\mathrm{PBBH})$ mencapai $R_{1},\left(0,067\right.$ gr) $R_{2}(0,058$ gr $)$ dan $R_{3}$ $(0,053$ gr), Hasil pengamatan $\mathrm{PBBH}$ ternak kambing kacang perlakuan $\mathrm{R}_{1}, \mathrm{R}_{2}$ dan $\mathrm{R}_{3}$ sebagai kontrol hampir sama karena di lakukan pada kondisi peternakan rakyat.

Tabel.2. Rata-rata Pertambahan Bobot Badan Kambing Kacang Selama 4 Bulan

\begin{tabular}{lcccc}
\hline Uraian & $\begin{array}{c}\text { BB.Awal } \\
(\mathrm{kg})\end{array}$ & $\begin{array}{c}\text { BB.Akhir } \\
(\mathrm{kg})\end{array}$ & $\begin{array}{c}\text { PBB/4 bln } \\
(\mathrm{kg})\end{array}$ & $\begin{array}{c}\text { PBB/bulan/Harian } \\
( \pm \text { gr })\end{array}$ \\
\hline Perlakuan $\mathrm{R}_{\mathrm{I}}$ & 14,33 & 22,44 & 8,11 & $2,02(0,067)$ \\
Perlakuan $\mathrm{R}_{2}$ & 14,34 & 21,76 & 7,01 & $1,75(0,058$ \\
Kontrol R $_{3}$ & 14,34 & 20,65 & 6,31 & $1,58(0,053)$ \\
\hline
\end{tabular}

Keterangan : PBB :Pertambahan Bobot Badan

Sumber data : Analisis data primer 
Tabel. 3. Hasil Uji t Perubahan Bobot Badan Ternak Kambing Kacang $\mathrm{R}_{1}, \mathrm{R}_{2}$ dan $\mathrm{R}_{3}$ di Tingkat Peternak (Kecamatan Tinggi Raja Kabupaten Asahan 2012)

\begin{tabular}{|c|c|c|c|c|c|c|}
\hline Bulan Ke & Skala Usaha & N- Observasi & $\mathrm{dk}$ & $\begin{array}{l}\text { Rata-rata } \\
\text { (kg) }\end{array}$ & T-test & Prob $|\mathrm{T}|$ \\
\hline \multirow[t]{3}{*}{ I } & Perlakuan $\left(\mathrm{R}_{1}\right)$ & & & 16,35 & & \\
\hline & Perlakuan $\left(\mathrm{R}_{2}\right)$ & 30 & 29 & 16,09 & 266,13 & 0,001 \\
\hline & Kontrol $\left(\mathrm{R}_{\mathrm{o}}\right)$ & & & 15,92 & & \\
\hline \multirow[t]{3}{*}{ II } & Perlakuan $\left(\mathrm{R}_{1}\right)$ & & & 18,37 & & \\
\hline & Perlakuan $\left(\mathrm{R}_{2}\right)$ & 30 & 29 & 17,84 & 456,34 & 0,001 \\
\hline & Kontrol $\left(\mathrm{R}_{\mathrm{o}}\right)$ & & & 17,5 & & \\
\hline \multirow[t]{3}{*}{ III } & Perlakuan $\left(\mathrm{R}_{1}\right)$ & & & 20,39 & & \\
\hline & Perlakuan $\left(\mathrm{R}_{2}\right)$ & 30 & 29 & 19,59 & 661,32 & 0,001 \\
\hline & Kontrol $\left(\mathrm{R}_{\mathrm{o}}\right)$ & & & 19,08 & & \\
\hline \multirow[t]{3}{*}{ IV } & Perlakuan $\left(\mathrm{R}_{1}\right)$ & & & 22,41 & & \\
\hline & Perlakuan $\left(\mathrm{R}_{2}\right)$ & 30 & 29 & 21,34 & 858,21 & 0,001 \\
\hline & Kontrol $\left(\mathrm{R}_{\mathrm{o}}\right)$ & & & 20,66 & & \\
\hline \multicolumn{2}{|c|}{$\begin{array}{l}\text { Perbedaan pada } \\
\text { bulan ke IV }\end{array}$} & 30 & 29 & 7,1433 & 1861,32 & 0,001 \\
\hline
\end{tabular}

Keterangan : N observasi $=$ jumlah pengamatan, $\mathrm{dk}=$ derajat kebebasan $(\mathrm{n}-1)$, PROB $|\mathrm{T}|=$ Probabilitas pada uji $\mathrm{T}$.

Sumber data: Analisis data primer

Hasil penelitian Zohdin (2012), yang dilakukan pada ternak kambing untuk mengetahui pertambahan berat badan kambing yang di berikan limbah kulit buah kakao yang di lakukan di desa Ongok, kecamatan Campalagian, kabupaten polmas, menunjukan bahwa pertambahan berat badan kambing mencapai rata-rata $0,239 \mathrm{~kg} /$ hari/ekor dan dan di desa Baruga Dua, Kecamatan Banggae, Kabupaten Majane, pertumbuhan berat badan kambing rata-rata menunjukan 0,184 $\mathrm{kg} /$ hari/ekor. Mathius et al., (1983) dengan menggunakan daun singkong segar sebanyak $200 \mathrm{gr} / \mathrm{ekor} / \mathrm{hari}$ didapatkan kenaikan bobot badan ternak kambing dan domba sebesar 66,9 gr/ekor/hari, sedangkan Rinto et al., (1995), melaporkan kambing dan domba diberi rumput lapangan dan konsumsi tepung daun singkong dengan tepung gaplek memperoleh kenaikan bobot badan sebesar 59,33gr/ekor/hari.

Hasil analisis untuk menguji antar perlakuan $\left(\mathrm{R}_{1}\right.$ dan $\mathrm{R}_{2}$ dan $\left.\mathrm{R}_{3}\right)$ digunakan uji statistik terlihat bahwa dari periode pengamatan bulan $1 \mathrm{~s} / \mathrm{d}$ ke 4 menunjukkan perbedaan sangat nyata $(\mathrm{P}<0,01)$ dimana terlihat bahwa bobot badan ternak kambing perlakuan $\mathrm{R}_{1}, \mathrm{R}_{2}$ dan kontrol $\mathrm{R}_{3}$ lebih tinggi perlakuan di banding dengan kontrol terlihat pada Tabel 3.

Penampilan produksi ternak kambing kacang menunjukkan bahwa perlakuan $\mathrm{R}_{1}, \mathrm{R}_{2}$ dan $\mathrm{R}_{3}$ sangat nyata $(\mathrm{P}<0,01)$ lebih tinggi dibanding ternak kontrol $\mathrm{R}_{3}$, sedangkan untuk mengukur tingkat pertumbuhan ternak kambing kacang pada perlakuan $\left(\mathrm{R}_{1}\right)$, dengan koefisien regresi yaitu $\mathrm{Y}_{\mathrm{k}}=14.33+2.02_{\mathrm{X}}\left(\mathrm{R}_{2}\right)$ dengan koefisien regresi yaitu $Y_{k}=14,34+1.75 x,\left(R_{3}\right)$ dengan koefisien regresi yaitu $Y_{p}=$ $14,34+1,58 \mathrm{y}$, diperoleh persamaan regresi dengan nilai $\mathrm{R}^{2}=0,99$ hampir sama. Tidak hanya petambahan berat badan saja yang terlihat pada ternak kambing kacang yang di beri hijauan pakan ternak Brachiaria Ruziziensis dan Stylosanthes Guianenis tetapi ternak kambing kacang tersebut lebih kelihatan cerah dengan yang bulu halus, mata berbinar, mulus, lincah dan sehat

\section{Analisis kelayakan usaha ternak kambing kacang}

Biaya yang dikeluarkan untuk usaha pemeliharaan ternak kambing kacang di peternak dengan skala 30 ekor adalah : Sewa lahan seluas $\pm 150 \mathrm{~m}^{2}$ sebesar Rp.450.000,/tahun, sehingga sewa lahan sebesar Rp.150.000,-/periode pemeliharaan, satu ekor kambing membutuhkan luas kandang individual $1 \mathrm{~m}^{2} /$ ekor sehingga luas kandang yang dibutuhkan $\pm 50 \mathrm{~m}^{2}$. Kandang dibangun berbentuk panggung (keraman), luas bangunan kandang total adalah $+50 \mathrm{~m}^{2}$ dengan biaya pembangunan Rp.75.000,- $/ \mathrm{m}^{2}$ dengan masa pakai 5 tahun, jadi pembangunan kandang sebesar Rp.3.500.000,-/5 tahun= Rp.750.000/ 
Tabel. 4. Analisis kelayakan usaha ternak kambing kacang

\begin{tabular}{|c|c|c|c|c|}
\hline No & Uraian & $\begin{array}{l}\text { Perlakukan } \mathrm{R}_{1} \\
\text { volume }\end{array}$ & $\begin{array}{l}\text { Perlakuan } \\
\mathrm{R}_{2} \text { volume }\end{array}$ & $\begin{array}{l}\text { Kontrol } \\
\mathrm{R}_{3} \text { volume }\end{array}$ \\
\hline 1 & A. Biaya Variabel & 800.000 & 800.000 & 800.000 \\
\hline \multirow[t]{6}{*}{2.} & B. Biaya Produksi : & & & \\
\hline & Bibit ternak 30 ekor rata-rata @ 589.650 & 17.689 .500 & 17.689 .500 & 17.689 .500 \\
\hline & $\begin{array}{l}\text { - Hijauan Brachiaria ruziziensis dan } \\
\text { Stylosanthes guianenis tidak beli }\end{array}$ & - & - & - \\
\hline & -hijauan lapang ed libitum & - & - & - \\
\hline & -obat-obatan /paket & 100.000,- & 100.000 & 100.000 \\
\hline & -tenaga kerja 2 org x Rp.300.000,- & 2.400.000,- & 2.400 .000 & 2.400.000,- \\
\hline \multicolumn{2}{|c|}{ Total Biaya Variabel + Produksi } & 20.989 .500 & 20.989 .500 & 20.989 .500 \\
\hline \multirow[t]{4}{*}{3} & C. Pendapatan & & & \\
\hline & - $\mathrm{R}_{1} \cdot(30-2 \%) \times \mathrm{Rp} .39 .500,-\mathrm{x} 22.02 \mathrm{~kg}$ & $25.223,910$ & & \\
\hline & $-\mathrm{R}_{2}(30-2 \%) \times \mathrm{Rp} .39 .500,-\mathrm{x} 21,76 \mathrm{~kg}$ & & 24.926 .080 & \\
\hline & $\left.-\mathrm{R}_{3}(30-2 \%) \times \mathrm{Rp} .39 .500,-\mathrm{x} 20,65 \mathrm{~kg}\right)$ & & & 23.654 .575 \\
\hline \multicolumn{2}{|r|}{ Total Pendapatan kotor } & $25.223,910$ & 24.926 .080 & 23.654 .575 \\
\hline \multirow[t]{2}{*}{4} & - Keuntungan /periode (4 bulan) & 4.235 .410 & 3.936 .580 & 2.665 .075 \\
\hline & - keuntungan bersih/bulan & 1.058 .602 & 984.145 & 666.268 \\
\hline 5. & $-\mathrm{B} / \mathrm{C}$ & 1,2 & 1,2 & 1,1 \\
\hline
\end{tabular}

Keterangan : $1 \%$ resiko kematian $\mathrm{R}_{1}, \mathrm{R}_{2}$ dan $\mathrm{R}_{3}$, perkiraan harga daging/kg Rp.39.500,

Sumber data : Analisis data primer

3bulan=Rp.250.000,-/periode, biaya penyusutan sebesar Rp.250.000,-/periode.

Transpor dari lokasi ketempat tujuan untuk pengangkut kambing disewa dua kali dalam satu periode sebesar Rp.150.000,-. Peralatan kadang Rp.175.000,- dan biaya tak terduga di pasar hewan Rp.75.000,- Untuk usaha pemeliharaan ternak kambing dengan skala 30 ekor dapat dilihat pada pada Tabel 4.

Tabel.4, menunjukkan perhitungan untuk biaya pakan hijauan Brachiaria ruziziensis dan Stylosanthes guianenis dihitung berdasarkan analisis usaha untuk mempermudah penghitungan biaya pada saat transaksi jual beli ternak kambing, kajian dari analisis usaha ternak kambing kacang dalam pemanfaatan hijauan pakan ternak yang telah disediakan dan ditanaman oleh petani di lahan perkebunan kelapa sawit yang berumur 5 tahun selama penelitian \pm 8 bulan dengan kontribusi ternak kambing kacang dengan pemeliharaan skala 30 ekor dan mortalitas kematian ternak kambing dihitung $1 \%$ dari masing-masing perlakuan $\mathrm{R}_{1}, \mathrm{R}_{2}$ dan $\mathrm{R}_{3}$.

Untuk perlakuan $\mathrm{R}_{1}$ di kandangan terus menerus, $R_{2}$ di kendangkan dan digembalakan (keduanya) dan $\mathrm{R}_{3}$ digembalakan terus menerus. Keuntungan yang diperoleh dari perlakuan $\mathrm{R}_{1}$ sekitar Rp.1.058.602/bulan dengan B/C 1,2, $\mathrm{R}_{2}$ sekitar Rp.984.145/bulan dengan $\mathrm{B} / \mathrm{C} 1.2$ disebabkan pengeluaran untuk biaya variabel dan biaya produksi, sedangkan untuk perlakukan $\mathrm{R}_{3}$ sekitar Rp. 666.268/bulan dengan $\mathrm{B} / \mathrm{C} 1,1$ biaya terkonsentrasi pada biaya yang dikeluarkan untuk tenaga kerja dan pembelian bibit.

Semakin tinggi nilai $\mathrm{B} / \mathrm{C}$ maka peluang usaha pemeliharan tertnak kambing tersebut makin mendatangkan keuntungan apabila diusahakannya dengan sungguh-sunggah dan menggunakan manajemen yang baik. Metode analisis ini membandingkan antara penerimaan dan biaya yang dikeluarkan pada suatu usaha ternak kambing dan apabila usaha dikatakan layak bila angka $\mathrm{B} / \mathrm{C}$ ratio-nya lebih besar dari pada $>1,-$.

\section{KESIMPULAN DAN IMPLIKASINYA}

Usaha ternak kambing kacang yang dilakukan oleh peternak di Kecamatan Tinggi Raja Kabupaten Asahan dan daya dukung lahan perkebunan kelapa sawit serta sumber daya pakan yang ada di lokasi penelitian. Diantara kemungkinan pemberian pakan tambahan tersebut yang berpeluang diterapkan pada petani peternak adalah bahan yang umumnya mudah didapat di pedesaan dengan harga yang terjangkau yakni hijauan pakan ternak Brachiaria ruziziensis dan Stylosanthes 
guianeniserta, dan limbah pertanian, yang dapat meningkatkan laju pertambahan ternak kambing kacang khususnya pola petani ternak kambing di pedesaan.

Penampilan produksi ternak kambing kacang menunjukkan bahwa perlakuan $\mathrm{R}_{1}, \mathrm{R}_{2}$ dan $R_{3}$ sangat nyata $(P<0,01)$ lebih tinggi dibanding ternak kontrol $\mathrm{R}_{3}$, sedangkan untuk mengukur tingkat pertumbuhan ternak kambing kacang pada perlakuan $\left(\mathrm{R}_{1}\right)$ dengan koefisien regresi yaitu $Y_{k}=14.33+2.02_{X}\left(R_{2}\right)$ dengan koefisien regresi yaitu $Y_{k}=14,34+1.75 x,\left(R_{3}\right)$ dengan koefisien regresi yaitu $\mathrm{Y}_{\mathrm{p}}=$ $14,34+1,58 y$ diperoleh persamaan regresi dengan nilai $\mathrm{R}^{2}=0,99$ hampir sama. Tidak hanya petambahan berat badan saja yang terlihat pada ternak kambing kacang yang di beri hijauan pakan ternak Brachiaria ruziziensis dan Stylosanthes guianenis tetapi ternak kambing tersebut lebih kelihatan bulu halus, mata berbinar, mulus dan sehat

Untuk perlakuan $\mathrm{R}_{1}$ di kandangan terus menerus, $\mathrm{R}_{2}$ di kandangkan dan digembalakan(keduanya) dan $\mathrm{R}_{3}$ di gembalakan terus menerus. Keuntungan yang diperoleh dari perlakuan $\mathrm{R}_{1} \quad$ sekitar Rp.1.058.602/bulan dengan B/C 1,2, $\mathrm{R}_{2}$ sekitar Rp.984.145/bulan dengan $\mathrm{B} / \mathrm{C} 1.2$ disebabkan pengeluaran untuk biaya variabel dan biaya produksi, sedangkan untuk perlakukan $\mathrm{R}_{3}$ sekitar $\mathrm{Rp}$. 666.268/bulan dengan $\mathrm{B} / \mathrm{C} 1,1$ biaya terkonsentrasi pada biaya yang dikeluarkan untuk tenaga kerja dan pembelian bibit.

\section{DAFTAR PUSTAKA}

Barnes, R.F and J.E. Baylor. 1995. Forages in a changing world. In: Forages, Vol 1: An intoducion to Grassland Agriculture, Barnes R.F., Miller D.A.and C.J. Nelson (eds.) 5th ed. Iowa State University Press, Iowa.

Departemen Pertanian \& DII. Statistik Pertanian, Kementrian Pertanian Republik Indonesia. Jakarta.

Hutasoit, R. 2009. Petunjuk Teknis Budidaya dan Pemanfaatan Braciaria Ruziziensis (Rumput Ruzi) Sebagai Hijauan Pakan Kambing. Pusat Penelitian dan Pengembangan Peternakan, 2009 Hal 1-45
Hutasoit, R. 2010. Pengaruh Pemberian Rock Phosphate dan Pupuk Hayati Terhadap Produksi dan Kualitas Stylosanthes Guianensis CIAT 184. Tesis Universitas Gadjah Mada, Yogyakarta 2010

Mathius.W.,Djadjanegara dan M. Rangkuti. 1983. Pengaruh Penambahan Daun Singkong (manihot utillisima) dalam Ransum Domba. Majalah Ilmiah Peternakan Vol.1.No.2 1983

Rinto A, R.S., H. Pulungan dan Kartiaso.1995. Pemanfaatan tepung daun singkong dan tepung gaplek sebagai makanan penguat ternak domba lepas sapih. Karya Ilmiah Fapet IPB, Bogor.

Sudjana, 1992. Metoda Statistika. Edisi ke 5, Tarsito. Bandung

Steel, G.D. Robert and James H. Torrie . 1980. Principles and Procedures of Statistics, Biometrical Approach 2nd Edition McGraw-Hill Book Company. New York. USA.

Satistik Pertanian Kabupaten Asahan 2011. Dalam Angka Sementara. Dinas Penyuluh Pertanian dan Peternakan Kabupaten Asahan Propinsi Sumatera Utara. 2011

Soekarwati, A.Soehardjo, K.L. Dillon, and J.B. Hhardaker. 1994. Ilmu Usahatani dan Penelitian untuk Pengembangan Petani Kecil. UI Press. Jakarta.

Simon.G. 2010. Beberapa Alternatif Skema Percepatan dan Penyebaran kambing Boerke. Prosiding Seminar Nasional Membangun Sistem Inovasi di Perdesaan. Balai Besar Pengkajian dan Pengembangan Teknologi Pertanian Bogor, 15-16 oktober 2009. Buku I. Hal. 246-255

Ketut Sutama.I. 2004. Tatangan dan Peluang Peningkatan Produktivitas Kambing Melaui Inovasi Teknologi Reproduksi. Prpsiding Lokarya Nasional kambing Potong, Pusslitbangnak Bogor, 6 Agustus 2003, hal, 51-60

Tatang.M.I. 2003. Strategi Penelitian Hijauan Mendukung Pengembangan Ternak Kambing Potong di Indonesia. Wartazoa Buletin Ilmu Peternakan Indonesia, Pusat 
Penelitian dan Pengembangan Peternakan Bogor, Vol. 13 No., 1 2003, hal 22-29

Tikupandang.A.A. Prabowo dan D. Sugandi. 1995. Aspek Tenaga Kerja Kelurga dalam Sistem Usahatani Ternak Terpadu di Daerah Transmigran Sulawesi Selatan. Prosiding Seminar Nasional Sains dan Teknologi Peternakan Pengelolaan dan Komunikasi Hasil-hasil Penelitian. Balai Penelitian Ternak Ciawi-Bogor, hal. 539545.

Utomo.U., T. Herawati dan S. Prawirodigdo. 2005. Produktivitas Induk Dalam Usaha
Ternak Kambing Kondisi Pedesaan. Prosiding Seminar Nasional. Teknologi Peternakan dan Veteriner, Pusat Penelitian dan Pengembangan Peternakan Bogor, 1213 September 2005, hal. 660-665

Zohdin. 2012 Pemanfaatan Limbah Kulit Buah Kakao (coklat) Sebagai Pakan Ternak Ruminansia Pemanfaatan Limbah Kulit Buah Kakao (coklat) Sebagai Pakan ... livestock-livestock. blogspot. com/.../ pemanfaatan-limbah-kulit-buah-kak..15 Jun 2012. Diambil tanggal 3 Desember 2012 